\title{
Altered pituitary hormone secretion in male rats exposed to Bisphenol $A$
}

\begin{abstract}
Bisphenol A (BPA) is a xenobiotic estrogenic compound. This compound has been suspected to have estrogenic effects on reproductive system of males and females. In this present study we investigated possible low-dose effects of BPA on Luteinizing Hormone in rats. Male Wistar rats (12-13 weeks old) were administrated a daily intra peritoneal $10 \mu \mathrm{g} / \mathrm{kgbw} / \mathrm{day}, 50 \mu \mathrm{g} / \mathrm{kgbw} / \mathrm{day}, 100 \mu \mathrm{g} / \mathrm{kgbw} /$ day dose of BPA for 6,6 , and 12 days, and one day after last injection, serum level of Luteinizing Hormone was examined by ELISA method. All data were expressed as means \pm SE. Two-way ANOVA was performed. Analysis of data showed that in all dose groups, plasma level of Luteinizing Hormone significantly decreased compared to control group. The present study showed that BPA at low doses affects Luteinizing Hormone, one of main hormones in spermatogenesis in the adult Wistar rats, and subsequently alters the steroidgenesis in testicular Leydig cells.
\end{abstract}

Key words: Bisphenol A, luteinizing hormone, spermatogenesis

\section{INTRODUCTION}

The substance 2, 2-bis (4-hydroxyphenyl) propane, more commonly known as bisphenol A (BPA), is used as a monomer in the manufacture of polycarbonates and epoxy resins, as an antioxidant in PVC plastics and as an inhibitor of end polymerisation in PVC. Polycarbonates are used in foodcontact materials such as returnable beverage bottles, infantfeeding bottles, tableware (plates and mugs) and storage containers. Epoxy resins are used in protective linings for food and beverage cans and vats. ${ }^{[1]}$

Much of the current focus in the endocrine disruption field surrounds the estrogenic action of various manmade chemicals. The ability of a chemical to bind to the estrogen receptor, either in vivo or in vitro, has been used as a definition of estrogenicity. Of concern is whether exposure to chemicals with steroid-like activity can disrupt normal endocrine function, leading to altered reproductive capacity, infertility, endometriosis, and cancers of the breast, uterus, and

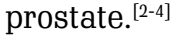

The xenoestrogens are a structurally diverse group of naturally occurring and manmade chemicals thtat mimic the actions of the female sex hormone estradiol. In the last decade, an increasing effort has been made to investigate the interactions between these chemicals (including various phenolic compounds, phthalate esters, phytoestrogens and certain pesticides) and the endocrine system of humans as well as several wild life species. A causative link between the exposure to environmental xenoestrogens and deterioration in male reproductive health and function has been proposed. ${ }^{[5]}$ Furthermore, an increased human exposure to these compounds and an apparent increase in prevalence of a range of hormonedependent human cancers of the reproductive tissue (breast, prostate, endometrium, testis and ovary) has been observed. ${ }^{[6,7]}$ One of the first chemicals discovered to mimic estrogen was the bicyclic aromatic compound bisphenol A (BPA). In 1936 BPA was found to stimulate growth of the rodent uterus, ${ }^{\left[{ }^{[8]}\right.}$ an indication of estrogenic action that has recently been confirmed by several in vitroand in vivo assays. ${ }^{[9,10]}$ Presently, BPA is widely used in the production of polycarbonate, epoxy resins (i.e., dental sealants and lacquer coatings of food cans), flame retarders and other products.

Male factor contributes to $40 \%$ of infertility cases worldwide. ${ }^{[1]]}$

Androgen biosynthesis by Leydig cell is under the control of the gonadotropin. LH, FSH release from
Gharravi A. M., ${ }^{1,2}$ Ghorbani R.',

Khazaei M. ${ }^{2}$, Pour Motabbad A ${ }^{3}$, Al Agha M. ${ }^{4}$, Ghasemi J. ${ }^{5}$, Sayadi P. ${ }^{6}$ ${ }^{1}$ Department of Anatomy, School of Medicine, Gorgan University of Medical Sciences, ${ }^{2}$ Department of Anatomy, ${ }^{3}$ Department of Physiology, ${ }^{4}$ Department of Pathology, School of Medicine, Kerman Shah University of Medical Science, Kerman Shah, ${ }^{5}$ Department of Chemistry, School of Sciences, Razi University, Kerman Shah,

${ }^{6}$ Department of Biophysics, School of Medicine, Kerman Shah University of Medical Science, Kerman Shah, Iran

For correspondence: A. M. Gharravi, Department of Anatomy, Gorgan University of Medical Sciences, Gorgan, Iran E-mail: annehgh@yahoo.com

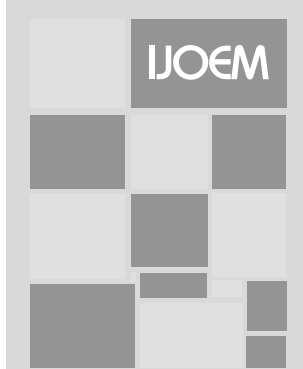


the pituitary is regulated by hypothalamic $\mathrm{GnRH}$, which signals through its receptors in pituitary gonadtropes. Effect of BPA on hypothalamus-pituitary-gonadal axis has not been clearly determined. Therefore, an objective of the present study was to determine whether exposure to environmentally relevant BPA levels affect pituitary LH secretion; we saw that BPA has inhibitory effect on pituitary LH secretion at lowdose exposure levels.

\section{MATERIALS AND METHODS}

In order to establish a dose-response relationship of the in vivo estrogenicity of BPA, albino rats were exposed to several concentrations of the compound. The goal of this study was to observe changes in hormone levels of $\mathrm{LH}$ following exposure to BPA.

\section{Animals}

Animals, 40 Wistar-derived strain adult male rats (12-13 weeks old and 200-250 g weight) were purchased from Razi Institute, Iran, and were housed in standard stainless-steel cages in animal lab of Kerman shah Medical College of Kerman shah University of Medical Science and exposed to a 12:12 h light:dark photoperiod at $\sim 20^{\circ} \mathrm{C}$ and $\sim 40 \%$ humidity and had free access to laboratory chow and tap water supplied from glass bottles. All rats were handled in accordance with the principles and procedures outlined in the Guide for the Care and Use of Laboratory Animals issued by the U.S. National Academy of Sciences.

\section{Dosage}

Animals were placed into eight experimental groups (5 rats in every group): vehicle-treated (control), $10 \mu \mathrm{g} / \mathrm{kg}$ body weight/day of BPA (10-BPA), and $50 \mu \mathrm{g} / \mathrm{kg}$ body weight/day of BPA (50-BPA), $10 \mu \mathrm{g} / \mathrm{kg}$ body weight/day of BPA (100-BPA) for 6 and 12 days (Table 1). Before and after study all rats were weighed.

BPA or its vehicle was administered continuously intraperitoneal [IP]. Dose levels for BPA $10 \mu \mathrm{g} / \mathrm{kg} / \mathrm{day}, 50 \mu \mathrm{g} /$ $\mathrm{kg} /$ day or $100 \mu \mathrm{g} / \mathrm{kg} /$ day were injected in 00:09 in morning by insulin syringe

Table 1: Dosage groups

\begin{tabular}{lccc}
\hline Group & \multicolumn{2}{c}{ Dosage } & Time \\
\hline 1 & Control & $\mathrm{D} / \mathrm{W}$ & 6 \\
2 & $\mathrm{BPA}$ & $10 \mu \mathrm{g} / \mathrm{kg}$ & 6 \\
3 & $\mathrm{BPA}$ & $50 \mu \mathrm{g} / \mathrm{kg}$ & 6 \\
4 & $\mathrm{BPA}$ & $100 \mu \mathrm{g} / \mathrm{kg}$ & 6 \\
5 & Control & $\mathrm{D} / \mathrm{W}$ & 12 \\
6 & $\mathrm{BPA}$ & $10 \mu \mathrm{g} / \mathrm{kg}$ & 12 \\
7 & $\mathrm{BPA}$ & $50 \mu \mathrm{g} / \mathrm{kg}$ & 12 \\
8 & $\mathrm{BPA}$ & $100 \mu \mathrm{g} / \mathrm{kg}$ & 12 \\
\hline
\end{tabular}

\section{Dosage preparation}

Appropriate amount of BPA was dissolved in $1 \mathrm{ml}$ ethanol and then diluted with distilled water. The final concentration of ethanol was $0.0001 \%$ in distilled water. Control rats received distilled water containing $0.0001 \%$ ethanol. ${ }^{[12]}$

\section{Hormone assays}

After one day, last-injection animals were anesthetized deeply by chloroform. About 2-3 ml of blood sample from ventricles of heart were collected in lab tubes and prepared for examination. After centrifuge serum detached and storage until hormone assay. Serum LH was quantified by ELISA method in Razi lab, Kerman shah, Iran. The assay was performed using the following materials supplied by Monobind and IBL Company. Assay was performed according to order of LH kits of Monobind and IBL Company. In summary, these steps were performed: washing buffer, specimen collection, assay procedure (incubation, enzyme conjugation, incubation, washing, substrate solution and reading at 450 $\mathrm{nm}$ within $30 \mathrm{~min})$. ELISA reader for this study was stat fax 2100 .

\section{Statistical analyses}

All data were collected and were expressed as means \pm SE. Data for each attribute were subjected to two-way analysis of variance. For determining of difference between groups, post-hoc (tukey test) was performed by spss statistical software (version 11.5). $P<0.05$ was significant. [Table 1]

\section{RESULTS}

Effects of various treatments on serum LH concentrations one day after dosing on adult rats are shown in Table 2, Figure 1. Serum level of LH in treatment groups was recorded and assessed. Statistically, difference in LH concentration was observed between the control and BPA groups. Analysis of data showed no difference between 6 and 12 days groups, but there was a difference between dosage groups. Interaction of days and dosage showed no difference. Analysis of data by post-hoc (tukey test) showed that the BPA-exposed groups had a significantly decreased mean concentration of serum LH when compared to the

Table 2: Serum level of several BPA exposed groups and vehicle groups

\begin{tabular}{lcc}
\hline Groups & Mean & Std. error \\
\hline control/6 & 0.6120 & 0.06967 \\
$10 \mu / 6$ & 0.1320 & 0.02956 \\
$50 \mu / 6$ & 0.1100 & 0.01000 \\
$100 \mu / 6$ & 0.1040 & 0.00245 \\
$\operatorname{con} / 12$ & 0.5860 & 0.04823 \\
$10 \mu / 12$ & 0.2820 & 0.15740 \\
$50 \mu / 12$ & 0.1900 & 0.06000 \\
$100 \mu / 12$ & 0.1100 & 0.01000 \\
\hline
\end{tabular}




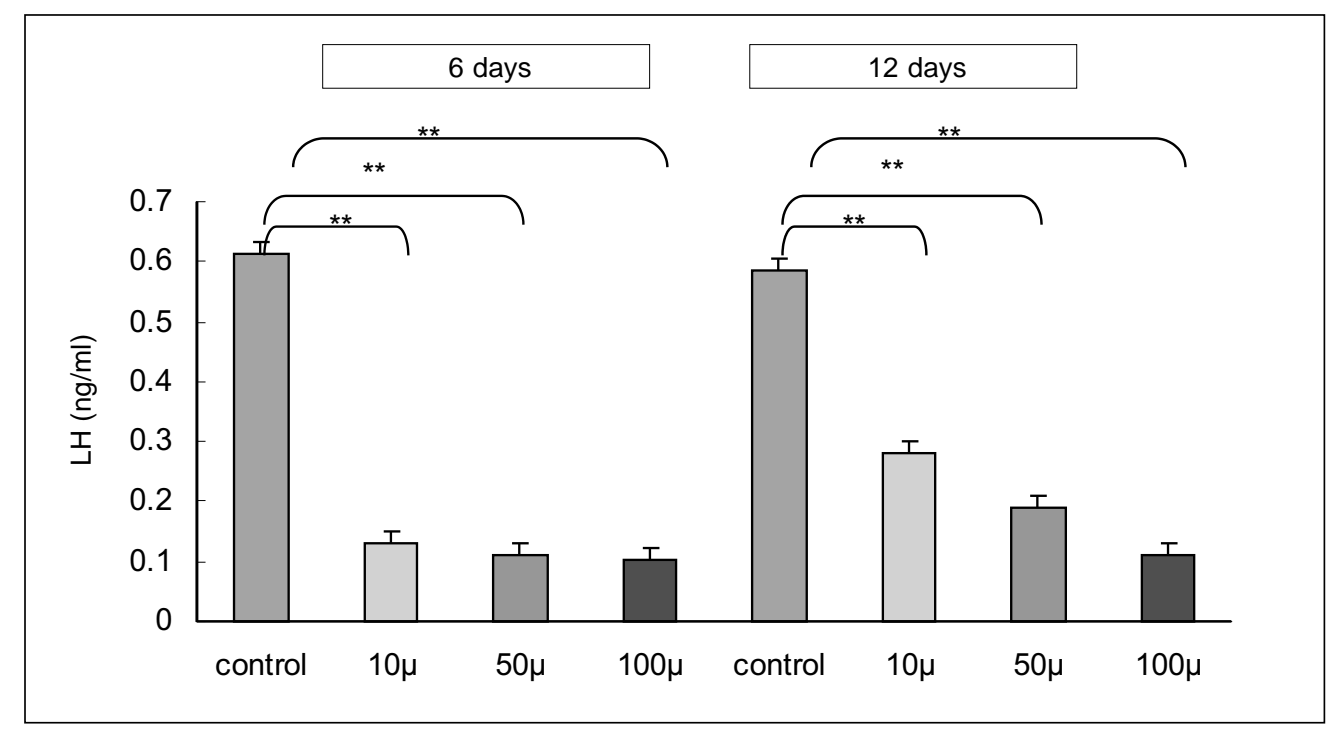

Figure 1: Effect of BPA on serum LH. Serum LH of BPA-exposed groups in both 6 and 12 days significantly decreased

injected controls $(P<0.005)$. (Table 2), (Figure 1)

\section{DISCUSSION}

The present study shows that a very low dose of BPA affects serum level of LH in adult rats. Exposure to substances that can mimic or disrupt the normal functioning of reproductive hormones has been linked to effects such as a reduction in fertility. Furthermore, numerous morphological effects have been noted in the offspring of rats exposed to sex-hormonedisrupting substances, including deformities of the reproductive tract, such as undescended testicles and hypospadias ${ }_{1}^{[13]}$ alterations in bone mass, ${ }_{1}^{[14]}$ as well as the other effects, which are not so immediately apparent, such as reduced sperm counts in males. ${ }^{[15]}$ Estrogen and androgen generally act by binding at receptor sites, and synthetic chemicals may disrupt this action in a number of ways. For example, a chemical may mimic the action of the natural ligand by being able to act on this receptor site, or it may interfere with the receptor in some other way, and be able to block the action of the hormone. ${ }^{[16]}$ Some chemicals can also perturb the normal functioning of the sex hormones by inhibiting the enzymes responsible for steroid hormone biosynthesis and/ or inducing enzymes responsible for steroid metabolism. ${ }^{[17]}$

Tohei showed that BPA increased LH concentration. ${ }^{[18]}$ He used high doses of BPA. It has been showed that BPA decreased LH concentrations. The present study was consistent with the observation of Chahoud, Liaw and Akingbemi. Chahoud showed that BPA in low doses affect LH concentration but this effect was not in high doses of BPA. ${ }^{[19]}$ Also, Liaw showed administration of BPA in utero decreased $\mathrm{LH}$ concentration. ${ }^{[20]}$ In another study, Akingbemi revealed that decreasing $\mathrm{LH}$ concentration after BPA exposition is a result of decreasing induction effect of LH synthesis in pituitary gland. ${ }^{[21]}$

The present study demonstrated that exposure of rats to environmentally relevant BPA levels has adverse effects on pituitary LH secretion. Exposure of adult rats [12-13 weeks old] to $10 \mu \mathrm{g} / \mathrm{kgbw} / \mathrm{day}, 50 \mu \mathrm{g} / \mathrm{kgbw} /$ day or $100 \mu \mathrm{g} / \mathrm{kgbw} / \mathrm{day}$ for 6 and 12 days, intra peritoneal, decreased serum level of LH. Decreasing serum level of LH was thought to be due to disruption of normal synthesis of LH in pituitary gland. These results support the hypothesis that exposure of adult rats to environmental doses of BPA induces alterations in the male reproductive axis, hormone secretion at different levels.

\section{ACKNOWLEDGMENTS}

We are extremely grateful to a number of Razi pathology lab at Kerman shah, particularly Rezvani, who developed the hormone assays we have used. We also thank Salimeh Gharravi, M. Zhaleh, M. Yadegari, G. H. Rajabi, and histology and pathology department of medical college, Kerman shah for their help. We are also grateful to the Kerman shah University of Medical Science, Iran.

\section{REFERENCES}

1. Opinion of the Scientific Committee on Food on Bisphenol A (Expressed on 17 April 2002) B-1049 Bruxelles/Wetstraat 200, B-1049 Brussel - Belgium.

2. Colborn T. Environmental oestrogen: health implications for humans and wildlife. Environmental Health Perspectives 1995;103:135-6.

3. Jensen TK, Toppari J, Keiding N, Skakkebaek NE. Do environmental oestrogens contribute to the decline in male reproductive health? Clinical Chemistry 1995;41:1896-901. 
4. Safe SH. Do environmental oestrogens play a role in development of breast cancer in women and male reproductive problems? Human and Ecological Risk Assessment 1995;1:17-23.

5. Toppari J, Larsen CJ, Christensen P, Giwercman A, Grandjean P, Guillette LJ, et al. Male reproductive health and environmental xenoestrogens. Environ. Health Perspect 1996;104:741-803.

6. Hoyer AP, Grandjean P, Jørgensen T, Brock JW, Hartvig HB. Organochlorine exposure and risk of breast cancer. Lancet 1998;352:1816-20.

7. Miller WR, Sharpe RM. Environmental Estrogens and Human Reproductive Cancers. Endocr-Relat. Canser 1998;5:69-96.

8. Dodds EC, Lawson W. Synthetic oestrogenic agents without the phenanthrene nucleus. Nature 1936;137:996.

9. Brotons FA, Olea-Serrano F, Villalobos M, Pedraza V, Olea N. Xenoestrogens released from lacquer coatings in food cans. Environ. Health Perspect 1995;103:608-12.

10. Olea N, Pulgar R, Pe'rez P, Olea-Serrano F, Rivas A, Novillo-Fertrell $\mathrm{A}$, et al. Estrogenicity of resin-based composites and sealants used in dentistry. Environ. Health Perspect 1996;104:298-305.

11. Sutovsky P. Yukihiro Terada and Schatten G: Ubiquitin-based sperm assay for the diagnosis of male factor infertility, Human Reproduction 2001;2:250-8.

12. Motoharu S, Seiichiro O, Ryuta I. Bisphenol A affects spermatogenesis in the adult rat even at a low dose journal of occuptional health 2001;43:185-90.

13. Kelce WR, Monosson E, Gamcsik M, Laws S, Gray LE. Environmental hormone disrupters: evidence that vinclozolin developmental toxicity is mediated by anti-androgenic metabolites. Toxicology and Applied
Pharmacology 1994;126:276-85.

14. Migliaccio S, Newbold RR, McLachlan JA, Korach KS. Alterations in oestrogen-levels during development affects the skeleton: use of an animal model. Environmental Health Perspectives 1995;103:95-7.

15. Sharpe RM, Skakkebaek NE. Are oestrogens involved in falling sperm counts and disorders of the male reproductive tract? Lancet 1993;341:1392-5.

16. Iguchi T. Cellular effects of early exposure to sex hormones and antihormones. International Review of Cytology-A survey of cell biology 1992;139:1-57.

17. Majdic G, Sharpe RM, O'Shaughnessy PJ, Saunders PTK. Expression of cytochrome P450 17á-hydroxylase/C17-20 lyase (P450c17) in the fetal rat testis is reduced by maternal exposure to exogenous oestrogens. Endocrinology 1996;137:1063-70.

18. Tohei A, Suda S, Taya K, Hashimoto T, Kogo H. Bisphenol A inhibits testicular functions and increases luteinizing hormone secretion in adult male rats. Exp Biol Med (Maywood) 2001;226:216-21.

19. Chahoud I, Talsness CE, Fialkowski O, Merker HJ. The effects of low dose prenatal bisphenol A exposure on male and female rat offspring. Teratology Apr 2001;63:13A-14A.

20. Liaw JJ, Stedman D, Gould JC, Elswick B, Welsch F. Reproductive development in female rats prenatally and lactationally exposed to bisphenol A. Toxicologist, 1998;42:176.

21. Benson TA, Chantal MS, Anna IK, Gary RK, Matthew PH. Inhibition of testicular steroidogenesis by the xenoestrogen Bisphenol A is associated with reduced pituitary cutinizing hormone secretion and decreased steroidogenic enzyme gene expression in rat; Endocrinology 2004;145. 